\title{
Energia tekstu. \\ Przeciwko krytyce etycznej
}

Tak jak w królestwie gwiazd niekiedy dwa słońca wyznaczają orbitę jednej planety, tak jak w pewnych wypadkach słońca o różnej barwie oświetlają ze wszystkich stron jedną i tę samą planetę, raz światłem czerwonym, raz zielonym, a innym jeszcze razem równocześnie je [sic!] trafiając i wieloma barwami zalewając: tak samo my, ludzie [...] jesteśmy określani [...] przez różne moralności [...] i dość często się zdarza, że dokonujemy wielobarwnych uczynków (F. Nietzsche, Poza dobrem i złem)1.

Wiersze tak doskonałe i rytmiczne, że z początku nie potrafimy uchwycić pełni ich sensu; przez kilka chwil czujna jest nadzieja i niepewność co do ich głębi. Ale trzeba tylko poczekać (W. Benjamin, Pasaże)².

Wstaję wraz ze stronicą, którą się otwiera, kładę się ze stronicą, którą się zamyka. Móc odpowiedzieć: „Należę do rasy słów, z których buduje się domostwa", doskonale wiedząc, że ta odpowiedź jest jeszcze jednym pytaniem, a to domostwo jest ciągle zagrożone

Przywołam księgę i postawię pytania.

Jeśli Bóg jest, to tylko dlatego, że jest w księdze; jeśli istnieją mędrcy, prorocy i święci, jeśli istnieją uczeni i poeci, jeśli istnieje człowiek i owad, to tylko dlatego [...] bo istnieje księga [...].

Księga jest dziełem księgi (E. Jabès, Księga pytań) ${ }^{3}$.

* Uniwersytet im. Adama Mickiewicza w Poznaniu, Wydział Filologii Polskiej i Klasycznej, Instytut Filologii Polskiej, Zakład Literatury XX wieku, Teorii Literatury i Sztuki Przekładu, e-mail: lapsang3@amu.edu.pl.

${ }^{1}$ F. Nietzsche, Poza dobrem i złem, przeł. P. Pieniążek, Kraków 2005, s. 129-130.

${ }^{2}$ W. Benjamin, Pasaże, przeł. I. Kania, Kraków 2005, s. 287.

${ }^{3}$ E. Jabès, Księga pytań, przeł. A. Wodnicki, Kraków 2004, s. 36-37. 
W ostatnich latach $\mathrm{w}$ literaturoznawstwie ${ }^{4}$ mamy do czynienia ze zjawiskiem - w mojej ocenie negatywnym - redukowania tego wszystkiego, co moglibyśmy nazwać niewyczerpywalną energią tekstu (zawsze wymykającego się wszelkim próbom zamykających go interpretacji, zawsze wieloznacznego i niejasnego, niemożliwego do finalnego poznania) do poziomu jednoznacznych, stereotypujących i banalizujących odczytań etycznych, niszczących wielopoziomowość dzieła i pozbawiających je energii znaczeniotwórczych. W tym niebezpiecznie dziś dominującym ${ }^{5}$ (symplifikująco tutaj określanym ogólną nazwą krytyki etycznej) ujęciu „interpretacyjnym” tekst jest pozbawiany swoich mocy i, stając się "głosem w sprawie", o którą bojuje krytyk-etyk, podlega nade wszystko jednoznacznym, wartościującym go pozytywnie lub negatywnie, ocenom.

Oczywiście można natychmiast postawić pytanie: czegóż chcieć od nobliwej etyki, dopełniającej, od czasów greckiego antyku, myśl filozoficzną i estetyczną? Zwłaszcza że etyk jest wiele, wypracowały one mrowie interesujących problematów i były przyczyną podejmowania szeregu niezmiernie inspirujących dyskusji, i tych moralnych, i poznawczych. Na fundamencie rozważań etycznych doprecyzowywano takie pojęcia, jak cnota, dzielność, przyjemność czy odpowiedzialność; pytano, jak działają i jak powinny działać wielkie dzieła literackie; rozmyślano, czy dobro jest koniecznym elementem piękna.

Nie etyki jednak dotyczy ten szkic. Etyka jest czymś pożądanym, a nawet koniecznym, również w literaturoznawstwie będącym częścią ludzkiego doświadczenia. Trudno zresztą wyobrazić sobie dyskurs, interpretację, działanie krytyczne czy sam artefakt jako jakości an-etyczne; gdyby takowe się pojawiły, właśnie ich usytuowanie (sama próba usytuowania) poza-etyką stanowiłoby o ich wymiarze moralnym. Deklarowana czy praktykowana czysta estetyka jest, choćbyśmy tego nie chcieli, wyborem wartości. Filipika zawarta w tym tekście nie jest przeto (nieskuteczną, wręcz niemożliwą) negacją bytu etyki; odnosi się ona do czegoś innego, do (głównie literaturoznawczej) krytyki etycznej w jej współczesnym wymiarze.

Krytyków etycznych niezbyt interesują wskazane wyżej zarówno przykładowe (niezmiernie wieloznaczne, dyskusyjne, wymagające ciągłej re-interpretacji) pojęcia etyczne, jak też same komplikacje zachodzące wewnątrz rozmaitych (częstokroć sprzecznych ze sobą) systemów etycznych, nie mówiąc już o metarefleksji powiązanej ze świadomością, że i sama etyka jest wytworem określonej kultury i w związku z tym wszystkie jej aksjomaty mają dyskursywny oraz historyczny charakter. Raczej przyświecają im hasła dominującej lub narzucanej innym określonej politycznej poprawności,

\footnotetext{
${ }^{4}$ Problem, który analizuję w tym tekście, przekracza granice literaturoznawstwa i dotyczy humanistyki w ogóle, a nawet można go zaobserwować w innych, niehumanistycznych obszarach wiedzy.

${ }^{5} \mathrm{Z}$ wolna można obserwować procesy odrzucania badań etycznych i ponownego powrotu do tekstów artystycznych, uznawanych za wartość samą w sobie. „Głosem za" chce być również ten szkic.
} 
nieustanny rewizjonizm i fundamentalne potępienie, czynione $\mathrm{w}$ duchu rozmaitych refleksji zorientowanych rasowo, płciowo, seksualnie, zaś ostatnio związanych z dość trywialnie rozumianymi prawami zwierząt. I znów - nikt dziś przy zdrowych zmysłach i o przyzwoitych, humanistycznych poglądach nie pragnie krzywdy zwierząt czy upokarzania rozmaitych mniejszości. Mimo to krytycy etyczni, w swej niekończącej się walce, wciąż wynajdują szereg nieprawomyślności, te zaś ich zdaniem są zapisane nade wszystko $\mathrm{w}$ tekstach literackich i artystycznych oraz w naszych codziennych zwyczajach językowych lub kulturowych. Jak pisał Edward W. Said - jeden z twórców postkolonializmu - wszystko, co napisali i powiedzieli biali Europejczycy na temat Wschodu, od czasów Homera, ma charakter rasistowski, imperialistyczny i etnocentryczny ${ }^{6}$.

Przyjrzyjmy się sprawie bliżej, dokonując subiektywnego i wybiórczego oglądu niektórych, obecnych w literaturoznawstwie tekstów i głosów. Sięgając natomiast do przykładów podkreślających szkodliwość pewnych procedur "analitycznych", warto przekroczyć granice literatury, by rzecz uczynić bardziej wyrazistą. W tym celu zamierzam też wskazać niektóre działania (z pozoru) naukowe.

Swego czasu problem podjęła Maria Janion w książce Humanistyka. Poznanie $i$ terapia ${ }^{7}$. W zgodzie $\mathrm{z}$ drugim członem tytułu autorka próbowała dowieść, że możliwe jest poznanie będące zarazem społecznym remedium na rozmaite istotności; projekt się nie powiódł i jej tekst jest raczej dowodem, że jeśli terapia staje się deklarowanym celem, to poznanie natychmiast

${ }^{6}$ Zob. A. Burzyńska, M.P. Markowski, Teorie literatury XX wieku, Kraków 2006, s. 549. Zdaniem cytowanego Saida: „Od czasów Homera każdy Europejczyk w tym, co mówił na temat Wschodu, był rasistą, imperialistą i [...] totalnym etnocentrykiem". Wszystko i wszyscy! Skoro tak, to, pragnąc być człowiekiem etycznym, należałoby chyba zaprzestać czytania jakichkolwiek dzieł (odnoszących się jakkolwiek do innych kultur) wytworzonych przez Europejczyków, by nie zatruwać swego umysłu tym paskudztwem. Bowiem jeśli je czytamy, to - wiedząc już o ich złej energii - wpadamy w jakże nieetyczny cynizm. Banał i bzdurność płynące z przytoczonej tezy Saida przekraczają granice absurdu. Co ciekawe, sami krytycy postkolonialni utracili poczucie, co i jak należy badać, i sami sobie chętnie zarzucają kolonializm. Zob. przykładowo spór pomiędzy M. Sahlinsem (Jak myśla "tubylcy". O kapitanie Cooku, na przykład) i G. Obeyesekerem (Apoteoza kapitana Cooka. Europejskie mitotwórstwo w rejonie Pacyfiku). W ogromnym skrócie można spór pomiędzy krytykami postkolonialnymi streścić następująco: Sahlins dowodził, że tubylcy ubóstwili kapitana Cooka, Obeyeseker potraktował to rozpoznanie jako potwarz dla tubylców, którzy - jakoby widząc białego - ujrzeli samego Boga; z kolei Sahlins za uwłaczające tubylcom uznał przekonanie swego oponenta, że mieliby oni myśleć jak biali i nie daje się im prawa dostrzec w Cooku bóstwa. Spór trwa, tubylców o zdanie nie spytano. Oczywiście polemikę badaczy, z wpisanym w nią ich zacietrzewieniem, czyta się doskonale. Wspomniany Said lubi słowa uogólniające. Wychodząc od analizy Jądra ciemności Conrada, dochodzi do uchwycenia istoty prozy, właściwie wszelkiej europejskiej prozy: „Każdy powieściopisarz oraz każdy krytyk i teoretyk europejskiej powieści zauważa jej instytucjonalny charakter. Powieść jest fundamentalnie związana ze społeczeństwem burżuazyjnym. Wedle wyrażenia Charlesa Morazé, powieść towarzyszy podbojom zachodniego społeczeństwa, a właściwie jest ich częścią [...]. Nie mniejsze znaczenie ma to, że gatunek zapoczątkowany został w Anglii przez Robinsona Crusoe" - E.W. Said, Kultura i imperializm, przeł. M. Wyrwas-Wiśniewska, Kraków 2009, s. 75-76 (podkreślenia w cytatach moje - P.G.).

${ }^{7}$ Wydanie pierwsze z roku 1974, drugie - z 1982. 
zostaje zredukowane i zmierza w kierunku antywiedzy. Porażka projektu przysłużyła się książce - trudnej, ale też fascynującej w lekturze, obrazującej stan teorii w latach 1890-1970.

Marta Nussbaum, jedna z najważniejszych etyczek, w szkicu Czytać, aby żyć łączy swe przekonania z poglądami Wayne'a Bootha, jednego ze współtwórców pojęcia krytyki etycznej. Obok licznych truizmów i niezweryfikowanych mniemań typu: „Ludzi obchodzą książki, które czytają” czy „Jeśli czytelnik jest osobą refleksyjną [...] stawia pytanie, na czym polega dobre życie" ${ }^{\prime \prime}$, buduje ona koncepcję przyjaźni zachodzącej pomiędzy odbiorcą a książką, z ukrytą tezą, iż przyzwoity człowiek nie posiada nieprzyzwoitych przyjaciół, ergo - nie należy czytać nieprzyzwoitych książek. To i tak umiarkowane oczekiwanie, częstokroć bowiem spotykamy się z etycznym cenzurowaniem tekstów lub żądaniem zakazu ich edycji. Przykładowo w Stanach Zjednoczonych usuwa się z pism Marka Twaina negatywne uwagi o Murzynach ${ }^{9}$, a do amerykańskiej ekranizacji Solaris Lema, w imię poprawności politycznej, wprowadzono (w miejsce jednego z białych mężczyzn przebywających w stacji kosmicznej) czarnoskórą kobietę. W tym, „poprawionym" w stosunku do ekranizowanej powieści filmie reżyser delikatnie sugeruje potrzeby homoerotyczne, eliminując jednocześnie, subtelnie przez Lema ukazany, fantazmat o charakterze pedofilskim, w konsekwencji zupełne nie wiadomo, po co błąka się po stacji mały chłopczyk. Cenzurowanie tekstów - kłopotliwe historycznie - z naukowego punktu widzenia jest szczególnie naganne; możemy nie lubić Twaina i potępiać pedofilię, ale jeśli chcemy poznawać określone teksty jako teksty czy jako fakty społeczne, to należy przyjąć je takimi, jakimi są, nie zaś fałszować.

Wspomniany Booth widzi (poczytajmy to za wartość jego rozważań) liczne słabości swej metody, która gubi złożoność formy literackiej, eliminuje jakości estetyczne dzieła, prowadzi do naiwnego, mimetycznego odbioru tekstu; wie też, że osąd etyczny jest subiektywny $i$ „znieczula” nas na książki - wszystko to jest jednak słuszną (zdaniem etyków) ceną za dobro „właściwej" lektury, która ponoć sprawi, że świat poprzez nas, nowych czytelników, będzie lepszy. O naiwności tego przekonania aż wstyd mówić. Ale pokreślmy w tym miejscu utopijność projektu: nie ma możliwości napisania dłuższego tekstu, który nigdy nikogo nie obrazi. Przykładowo (sięgnijmy po ceniony przez etyków przykład z tak zwanego życia) miałem kiedyś

\footnotetext{
${ }^{8}$ Zob. ten i inne szkice problemowe poświęcone krytyce etycznej zawarte w tym numerze pisma - „Teksty Drugie” 2002, nr 1-2. Cytaty z Nussbaum ze s. 8. W numerze spotykamy również zasadniczą krytykę jej poglądów teoretycznych w tekstach Noëla Carrolla i Agaty Bielik-Robson.

${ }^{9}$ Prowadzi to do interesującego sporu „etycznego", którego granice wyznaczają przeciwstawne poglądy: książki (te „podejrzane”) wydajemy bez cenzury, z ewentualnym komentarzem; cenzurujemy je, fałszując historię oraz wiedzę o kulturze; nie wydajemy ich wcale, odmawiając im prawa do istnienia. Sam Twain używał pejoratywnego określenia "czarnuchy" - świadczy to o samym Twainie, o jego czasach, o określonej przestrzeni społecznej; cenzura świadczy natomiast o nas. W moim odczuciu fałszowanie zdarzeń, mimo wszystko, mimo „szlachetnych" intencji, nie może dać pozytywnych etycznie rezultatów.
} 
studentkę odmawiającą lektury tekstów, w których pojawiały się - jak to mówi się dzieciom - "brzydkie wyrazy” oraz sceny przemocy, odmawiającą, gdyż wychowano ją w ten sposób, że szanująca się kobieta w czymś takim nie uczestniczy. Cóż jednak począć z faktem, że jak jednych obraża brak/obecność określonych postaci w tekstach lub pojawianie się pewnych słów, tak innych może obrażać ignorancja estetyczna, narzucanie im cudzych przekonań etycznych, wreszcie - „pochwalana” przez Erazma z Rotterdamu głupota? W czasach dominacji teorii strukturalnych istniała na to doskonała odpowiedźc ${ }^{10}$ - literatura to papier, fakty tam przedstawione składają się ze słów, a ich referencja jest problematyczna. Tym samym, przykładowo, Izabela Łęcka, mimo iż reprezentuje konkretny typ ludzki, jest jednak nade wszystko postacią literacką i ślub z nią nie jest w normalnym życiu możliwy - zatem nie jest ona ani dobra, ani zła ${ }^{11}$, tylko fikcyjna! Poststrukturalizm w ogóle odrzucał referencję, zastępując ją pojęciem symulakrum czy terminem reprezentacji. Natomiast krytycy etyczni, jakby nigdy nic się w teorii nie wydarzyło, w duchu własnych "najnowszych" badań pozytywistycznych, potępiają postacie, zdarzenia, autorów, a nawet czytelników, jakby wszystko, co napisane (uniwersum literackich artefaktów), nie działo się w języku, chwycie, tekście. Przeciwnie - było namacalne i dotykalne; prawdziwe. Właściwie: Prawdziwe (pisane wielką literą). By nie krzywdzić krytyki pozytywistycznej, warto przypomnieć, że w swoich najlepszych realizacjach, przykładowo Hipolita Taine'a, postulowała ona, obok oceny dzieła i twórcy dokonywanej pod kątem spełnionych lub nie powinności społecznych, badanie "geniuszu indywidualnego", czyli pierwiastka sensotwórczego, realizującego się w języku. Ów geniusz sprawia, że dawne dzieła potrafią się nie starzeć i dostarczać nam nieustannie nowych wzruszeń estetycznych. Zapewnia on wieczną energię arcydziełom, energię, którą krytycy etyczni chcą teksom zabrać, wrzucając je w swoje etyczne mniemania. Choćby z tego powodu krytyka etyczna jest nieetyczna!

Pragnąc rzecz uczynić jeszcze bardziej problematyczną, sformułować należy dwa aksjomaty. Pierwszy: jeżeli obok nas ktoś dostanie ataku padaczki, etyczne jest udzielenie mu pomocy; nie jest natomiast czymś etycznym formułowanie tezy, że należy lub też nie należy w takiej sytuacji pomagać12. Etyczne bowiem są czyny, nie dyskursy i żaden krytyk etyczny gaworzący o lepszym świecie nie opuszcza przestrzeni rozmowy, z której do etyczności droga daleka.

${ }^{10}$ Podtrzymuje ją dziś dobitnie T. Eagleton, podkreślający często, że postacie z książki żyją i działają wyłącznie $\mathrm{w}$ danej książce i to jedynie $\mathrm{w}$ trakcie aktu lekturowego. Zob. też P. Graf, Stare dobre czytanie, [online] http://fp.amu.edu.pl/pawel-graf-stare-dobre-czytanie/ (dostęp: 23.07.2017).

${ }^{11}$ Miałem kiedyś osobliwą przyjemność wysłuchania na jednej z konferencji naukowych tyrady o tym, jak złym człowiekiem jest Łęcka i dlaczego powinna zostać przez nas (nas?) potępiona za swe życiowe wybory.

${ }^{12} \mathrm{O}$ tym, jak różne są etyki, niech poświadczy fakt, iż święty Bazyli Wielki, doktor Kościoła, uważał, że ubogim można, jeśli takie mamy pragnienie, dawać jałmużnę, ale że etyka chrześcijańska tego od wiernych nie wymaga. Uzasadniał to przekonanie sensownością i całością bytu, w ramach którego ubodzy są czymś koniecznym. 
Czyniąc, działamy w sferze etyki $\mathbf{i}^{13}$, dyskutując, działamy w sferze dyskursu. Mówienie o moralności nie jest tożsame z moralnością, a w zasadzie ma z nią niewiele wspólnego. Aksjomat drugi: a jaka to etyka miałaby obowiązywać? Jak obrazowo wyraził to Fryderyk Nietzsche, żyjemy poza dobrem i złem, co można współcześnie zinterpretować - nie ma czynu, który w każdym miejscu i czasie byłby przez wszystkich uznany za zły lub dobry. Dlatego nie mamy żadnej etyki (liczba pojedyncza), tylko mamy etyki (liczba mnoga). Jedną $\mathrm{z}$ bardziej interesujących (moim zdaniem) zaproponował $\mathrm{w}$ ostatnim czasie Zygmunt Bauman, mówiąc o tym, że człowiek etyczny pragnie, by czyny jego były docelowo dobre; ale ponieważ skutki jego czynu nie są mu, w chwili jego popełniania, znane, pozostaje on w drżeniu i bojaźni, pragnąc i mając nadzieję, że nie popełnił zła. Sama etyczna wartość czynu (czynu, nie dyskursu etycznego) zostanie określona przez nieznaną nikomu przyszłość. Wspiera to rozumowanie choćby jeden z wierszy Wisławy Szymborskiej, w którym poetka kieruje swą uwagę na pewne małe, niewinne, słodkie dziecko. Bobasa Adolfa, którego znamy jako Hitlera. Instynktownie ciśnie się na usta pytanie, czy aborcja w tym przypadku byłaby dobrem, czy złem. Jednak $w$ tej sytuacji nawet Baumanowska etyka nie jest w stanie "udzielić odpowiedzi", skutki bowiem takiego czynu nie byłyby poznawalne. A przecież istotnych etyk, zupełnie odmiennych od Baumanowskiej, powstałych jedynie w obrębie kultury europejskiej, jest kilkadziesiąt. Skąd mielibyśmy wiedzieć, która z nich to ta odpowiednia? I dalej: co jest słuszne?

Krytycy etyczni jednak „wiedzą", że etyka jest jedna (są to z reguły ich własne przekonania moralne) i w związku z tym również doskonale zdają sobie sprawę z tego, które czyny i poglądy są dobre, a które złe. Co więcej, oczekują oni, że ich "wiedza" stanie się normą prawną, powszechną i obowiązująca - co natychmiast prowadzi do segregacji ludzi na dobrych (myślą jak my) i złych lub naiwnych; do apriorycznego wykluczania pewnych tekstów, postaw, a nawet pytań sprzecznych z oczywistą przecież prawdą; w rezultacie - do dogmatyczności. Zresztą kolejny problem polega na tym, iż każda etyka - co wykazywał już Sokrates - jest aporetyczna i dochodzi do samozaprzeczenia; weźmy system Tadeusza Kotarbińskiego, jego traktat o dobrej robocie. Dobry, etyczny krawiec to ten, który szyje dobre spodnie... A złodziej?

W szkicu Nussbaum mamy niemało tez zdecydowanie dyskusyjnych - otóż chwaleni przez nią autorzy, jak William Szekspir, Lew Tołstoj czy Miguel de Cervantes, byli przez innych etyków ostro ganieni; książkę Hermana Melville'a o pogoni za wielorybem wielu uznałoby w określonej etyce (dzielność, niezłomność itp.) za dobrą - ja, jak i pewnie kilkoro innych czytelników, wyjątkowo jej nie lubię... Sami czytelnicy są bowiem różni, co jednemu szkodzi, drugiemu służy. A postulowana przez nią przyjaźń nie

${ }^{13}$ Moralność ściśle wiąże system etyczny z działaniem i z koniecznością; w moim przekonaniu albo myślimy o etyce jako moralności, etyka jest czynem; albo myślimy o dyskursywnym systemie etycznym. Rozważania typu: jak być powinno, co należy, czym jest dobro, stanowią odmianę filozofii i usytuowane są poza działaniami, nie mogą warunkować etycznych roszczeń, zwłaszcza skierowanych w stronę faktów artystycznych. 
zawsze jest bezproblemowa, przykładowo wymykają się jej teksty filozoficzne, co prowadzi nas do takiego zdania: „Filozofia również potrafi uwodzić. Potrafi odciągać czytelnika od bogatego świata konkretów w stronę górnych i pustych abstrakcji. Ona także potrafi obiecywać ucieczkę od świata trudnego i chaotycznego w świat schematyczny i uproszczony. Ten rodzaj uwiedzenia może okazać się szczególnie niebezpieczny"14. Hm, kto, spytajmy, miałby skutecznie ocenić, co jest, a co nie jest pustą abstrakcją? Czy osoby, które z powodu swej kondycji intelektualnej nie potrafią czuć się dobrze w zbyt skomplikowanej rzeczywistości, nie powinny redukować jej do bezpieczniejszych schematów? Dla kogo niebezpieczny i dlaczego?

By unaocznić o co chodzi, przywołajmy trzy przykłady, tym razem nie tyle literackie, co humanistyczne. Na jednej z konferencji - jeszcze jedna egzemplifikacja z życia naukowego - referat przedstawiała późnofeministyczna zwolenniczka animal studies. Wychodząc od (literackiego!) opisu umierającej krowy, której nikt z ludzi (fikcyjnych bohaterów tekstowych) nie pomaga, doszła do krytyki męskiego świata (?), w którym dochodzi do aktów okrucieństwa wobec zwierząt. Pominąwszy fakt, iż w świecie zwierząt inne osobniki też sobie na ogół $\mathrm{w}$ takiej sytuacji nie pomagają (zwłaszcza międzygatunkowo) i ewentualnie dochodzi do procesu wzajemnego zjadania - niezbyt wiadomo, po co uruchomione zostały aluzje do świata mężczyzn. $\mathrm{W}$ to miejsce referentka nie zwróciła uwagi na podstawowe dla rozumienia literatury fakty: kto o tym mówi?, w jakim trybie mówi?, czy przypadkiem nie jest to cytat?, a może to sen? - tak jakby to autor mówił wprost do czytelnika o istniejącym świecie, oskarżając mężczyzn o obojętność wobec cierpiącego zwierzęcia ${ }^{15}$. Dochodzi w takim rozumowaniu do cofnięcia literaturoznawstwa na pozycje zajmowane przez wiedzę o literaturze jakieś sto, sto dziesięć lat temu, do zapomnienia, że literatura nie jest mówieniem wprost, a jej sensy są wielorakie i nade wszystko stanowią pochodną interpretacji. I jakkolwiek makabryczna może być konkretna scena przemocy, sprowadzanie do niej tekstu, odrzucenie języka i jego znaczeniotwórczej roli jest pozbawieniem literatury jej energii, zniszczeniem jej walorów, jest zamianą dzieła artystycznego w gazetę donoszącą o okrucieństwach wokół nas.

Przykład drugi niech będzie z przeciwnej strony etycznej barykady. Znana jest sprawa Lecha Wałęsy, któremu zarzucono między innymi, że „sikał do kropielnicy". Rozumowanie było tu dość proste: oto Wałęsa twierdzi, że jest wierzący, czyli, konsekwentnie, nie kłamie (grzech), mówiąc, że nigdy nie był agentem; ale faktycznie nie jest wierzący, bo wszak sikał do kropielnicy, bezczeszcząc sacrum; zatem kłamie, co tym samym dowodzi, że agentem był. Bardzo to misterne, ale nienaukowe. Dla mnie nie tyle interesujący jest problem agenturalności Wałęsy, co jawna rezygnacja, w imię określonej etyki, z naukowego podejścia badawczego. Zastosowanie sensownych

${ }^{14}$ „Teksty Drugie" 2002, nr 1-2, s. 17.

${ }^{15}$ Powiedzmy też brutalnie, że nawet największa miłość do zwierząt niczego nigdy nie zmieni w sytuacji tej konkretnie fikcyjnej krowy. Każdorazowy akt lektury będzie skutkował jej ponowną śmiercią w obrębie świata przedstawionego. 
procedur poznawczych sprawia, że należy, ustalając "sprawę kropielnicy", zbadać określone relacje świadków w określony sposób. Jak wiadomo, Wałęsa jest niskiego wzrostu. W jaki zatem sposób sikał do kropielnicy? Może przyciągnął sobie ławkę? A czy wówczas w tym kościele były ławki? Może były tam krzesełka? Lub ławki przytwierdzono do podłogi? Wówczas relację należałoby sfalsyfikować. Takie pytania jednak nie zajmowały młodego etycznego historyka, który nie interesował się historyczną akrybią, lekceważąc ją w imię jakże ważniejszej dla niego etyki, na mocy której przyznał sobie mandat, by uczynić świat lepszym. A że wiarygodne badania historyczne czy antropologiczne wyglądają inaczej? Któż by się tym przejmował?

Przykład trzeci dotyczy Murzynka Bambo. Otóż ten znany wiersz dla dzieci, napisany przez Juliana Tuwima, został uznany za kolonialny i niegod$n^{16}$. „Murzynek - dowodzi autor etycznej interpretacji - jest upośledzony, jest Innym wymagającym uleczenia". Jego imię konotuje bambus, to zaś (Tuwim to najprawdopodobniej zamierzył) jest wybitnie pejoratywnym określeniem ludzi czarnoskórych. Bambo się nie kąpie, nieustannie psoci i figluje. W konsekwencji, w zakończeniu wierszyka, tylko pozornie dzieci mówią: „Szkoda, że Bambo czarny, wesoły / Nie chodzi razem z nami do szkoły"; w rzeczywistości mówią: gdyby Bambo nie był Bambem, to byśmy go lubili, a tak to nie. W przypadku, kiedy ta interpretacja oznaczałaby filologiczny żart, byłaby przezabawna, niestety jest ona rozpatrywana całkowicie poważnie, niezbyt wiele w niej znajdziemy poczucia humoru. Notabene, ostatnio zaatakowano również, nawiązującą ponoć do wiersza Tuwima, margarynę Palmę, na owijce której jest, podobny Bambu, Murzynek ${ }^{17}$. Poproszony o komentarz językoznawczy Jerzy Bralczyk potwierdził, że samo słowo murzynek przywołuje leksem żydek, jeszcze bardziej negatywny niż forma wyjściowa Żyd poprzez swe zdrobnienie. Czemu zdrobnienie (zwłaszcza w tekstach dla dzieci) negatywizuje - nie wiem; natomiast słowo Murzyn ma swoją historię. Jest ono przekształceniem wyrazu Maur, pierwotnie oznaczającego właśnie ludzi o ciemnym kolorze skóry, nieposiadającego żadnych negatywnych konotacji. Etymologiczne historie słów, wymagające zabiegów rekonstrukcyjnych, nie są jednak ciekawe dla etyków poszukujących u bliźnich nade wszystko złych zamiarów. O „modzie" wśród awangardzistów na "tropiki" nie warto nawet wspominać ${ }^{18}$.

Czy nie istnieje możliwość sensownego wprowadzenia problematyki etycznej do rozważań literaturoznawczych? Oczywiście, że tak; tyle tylko, że wówczas dany badacz nie zajmuje się uprawianiem etyki (dyskursywnego krytycyzmu wobec inaczej myślących), ale bada relacje zachodzące pomiędzy pierwiastkiem etycznym a estetycznym. Etyka tym samym jest

${ }^{16}$ „Teksty Drugie" 2005, nr 1-2, s. 259-270.

17 Zob. http://wiadomosci.gazeta.pl/wiadomosci/1,114871,15684470,Kultowa_margaryna_z__ Murzynkiem_oburza_Afrykanczykow.html\#MT (dostęp: 23.07.2017).

${ }^{18}$ Przykładowo futuryści urządzali „Wieczór białych Murzynów”, pisali teksty, w których porównywali się z Murzynami; podobne rzeczy znajdziemy w utworach na przykład Zegadłowicza. Modę tę w pewien sposób zapoczątkował F.T. Marinetti, wpisując swe teksty w przestrzeń afrykańską. 
dla niego dopełnieniem innych jakości dzieła, nie jest narzędziem służącym krytyce czytanych autorów, tekstów i ich „bezkrytycznych” czytelników ${ }^{19}$.

Tu pora przyznać, że sam spór pomiędzy teoretykami, nazwijmy ich umownie "klasycznymi”, a krytykami etycznymi jest jałowy; pierwsi nieustannie wskazują na uproszczenia, manipulacje tekstem, sprowadzanie dzieł artystycznych do mimetycznych obrazków... Drudzy zawsze powiedzą: „A wy jesteście nieetyczni”.

Sprawa jest zatem znana i beznadziejna. Już Konstanty Troczyński w latach trzydziestych poprzedniego wieku w artykule o moralistach pisał o zubożeniu sztuki, którą niektórzy pragną sprowadzać wyłącznie do tak zwanych wartości społecznych. Nie czynią tego bezinteresownie: „Teza o sztuce jako wartości przede wszystkim społecznej [...] jest racją tych wszystkich, którzy pragną posłużyć się nią jako narzędziem. Rozumiejąc dobrze siłę napięcia, jakie wywołuje sztuka, czując potęgę, jaka tkwi w zjawisku estetycznej sugestii, pragną oni skierować ją jako siłę popędową do własnego motoru"20; a przecież: „Nie wszyscy zupełnie jasno zdajemy sobie sprawę z tego, że pisarstwo, literatura, a więc i sztuka w ogólności posiada swoisty, jej tylko właściwy porządek moralny. [...] Dlatego to, choć istnieje system norm moralności pisarskiej, nie ma w zwykłym znaczeniu tego wyrazu przestępców prawa artystycznego. Są tylko artyści, którzy wyczuwają wewnętrzne moralne konieczności sztuki, i artyści, którzy ich nie wyczuwają"21.

Sztuka podróżowania pomiędzy tekstami - literackimi, muzycznymi, malarskimi czy architektonicznymi - polega na tym, by przyjąć je w ich bogactwie, niewyrażalności, fluktuacji. By - parafrazując Witkacego - okazać im swe nienasycenie i przyjąć ich bebechowatość. Nie należy wielkich dzieł krzywdzić swoim, osadzonym w przypadkowości, etycznym roszczeniem. No chyba, że dzieła te są dla nas kompletnie nieważne. Nawet wtedy warto jednak pamiętać o słowach starego Żyda, przytoczonych przez Czesława Miłosza w Zniewolonym umyśle, że jeśli ktoś ma sto procent racji, to wielki jest $\mathrm{z}$ niego nikczemnik i trzymać się należy od niego $\mathrm{z}$ daleka.

„Dzieło sztuki - zdaniem Iwony Lorenc - to fenomen par excellence. Jego rzeczywistość nie jest tym, do czego ono odsyła i co zastępuje. Jest raczej tym, co się samo w sobie ukazuje. Ukazuje się zaś jako naprzemienna, dialektyczna (skrywająco-odkrywająca) gra tego, co się ukazuje, i tego, jak się ukazuje"22.

A dobro? Dobra dla energetycznej równowagi w świecie nie powinno być nazbyt wiele - jak to dowcipnie i paradoksalnie ukazał Karel Čapek

${ }^{19}$ Można przywołać liczne nazwiska krytyków zajmujących się etyką w interesujący sposób, niebędących zarazem zwolennikami jałowej krytyki etycznej, choćby: K. Arbiszewskiego, A. Bielik-Robson, M. Dąbrowskiego, S. Dąbrowskiego, D. Szajnert, D. Ulicką. To jednak byłoby nadmiernym otwarciem tego polemicznego szkicu na zupełnie odmienną opowieść. Zob. M.P. Markowski, Zwrot etyczny w badaniach literackich, „Pamiętnik Literacki” 2000, z. 1.

${ }^{20}$ K. Troczyński, Od formizmu do moralizmu. Szkice literackie, [w:] tegoż, Pisma wybrane, t. 1, Kraków 1997, s. 326.

${ }^{21}$ Tamże, s. 330.

${ }^{22}$ I. Lorenc, Minima aesthetica. Szkice o estetyce późnej nowoczesności, Warszawa 2010, s. 117. 
w Fabryce absolutu. Skonstruowana maszyna nieustannie produkowała dobro, przenikało ono świat oraz ludzi i - w efekcie jego nadprodukcji - nieoczekiwanie doszło do wielkiej wojny, w której niemal wszyscy się pomordowali. Jedynie oniryczna poetyka tej powieści przyniosła ocalenie, nazbyt zanurzonej w absolucie, ludzkości. Wtóruje temu Alberto Savinio, który w Nowej Encyklopedii (tytuł odsyła oczywiście do Encyklopedystów) wyklina Sokratesa odpowiedzialnego - jego zdaniem - za dowartościowanie, niewiele wcześniej znaczącego, sumienia - owej „ludzkiej ułomności”, która, rozwinąwszy się przez wieki, zaczęła niszczyć ludzi na wszelkie sposoby ${ }^{23}$.

W świecie obserwujemy pewne tajemnicze, niewytłumaczalne działanie. Otóż w sposób konieczny potrzebujemy etyki, pragniemy doświadczać jej działania. Teksty artystyczne są w tym przypadku jedną $\mathrm{z}$ istotnych form etycznego oddziaływania. Ich energia stwarza najważniejsze pytania, podsuwa odpowiedzi. Natomiast etyczne roszczenia formułowane pod adresem tych tekstów, z pozoru szlachetne i słuszne, niewiele z etyką mają wspólnego. No i nade wszystko niszczą energię dzieł, są dla nich niczym cios opisany we fragmencie jednej z pieśni Wergiliusza:

(Prawą zamachnął się ręką, okrytą twardym rzemieniem,

Z góry wymierzył cios pomiędzy rogi i oto

Pękła czaszka, a pięść Entellowa w mózgu ugrzęzła) ${ }^{24}$.

Co ocali teksty przed krytyką etyczną? Pozwoli zachować ich energię, różnorodność, wpisane $\mathrm{w}$ nie rozterki, również nieetyczności?

Zamiast odpowiedzi przywołajmy fragment wiersza Anny Piwkowskiej:

\section{Po-etyka}

A może jednak poetyka jest po etyce

a nie odwrotnie?

Może kiedy moknie

manuskrypt i rozpuszcza litery atrament

żaden bezsens i bezdech, i zamęt

nie wprawia niebieskich sfer w prostrację?

A może każdy poeta

wierząc w sens swoich fraz i we frazę

tę ostatnią, dantejską, ma rację,

że każdy wiersz ma sens

symboliczny i etyczny zarazem?25

${ }^{23}$ Zob. A. Savinio, Nowa Encyklopedia, przeł. S. Kasprzysiak, Warszawa 2015, s. 148-149.

${ }^{24}$ Wergiliusz, Eneida, przeł. I Wieniewski, ks. V, w. 474-476.

${ }_{25}$ Zob. http://malowane-wierszem.blogspot.com/2015/10/po-etyka-anna-piwkowska.html (dostęp: 23.07.2017). 
oraz dwa poglądy, a może rady. Pierwsza pochodzi z Nietzscheańskiego motta tych rozważań: jako ludzie powinniśmy sobie najwięcej cenić wielokolorowe czyny i wielobarwny świat; różne moralności. Rada druga pochodzi od Richarda Rorty'ego, który ku zbyt napiętym w swych poglądach ludziom, tym, którzy ciągle są na ideowym froncie, dawał prosty aforyzm, używając rozkaźnika: „Rozluźnij się”. A to rozluźnienie może sprawi - to już nie Rorty - że wyzwoli się nieskończona energia tekstu i to ona właśnie uczyni świat nieco lepszym.

\section{BI B L IOG R A F I A}

Benjamin W., Pasaże, przeł. I. Kania, Kraków 2005.

Burzyńska A., Markowski M.P., Teorie literatury XX wieku, Kraków 2006.

Graf P., Stare dobre czytanie, [online] http:/ / fp.amu.edu.pl/pawel-graf-stare-dobre-czytanie/ (dostęp: 23.07.2017).

Jabès E., Księga pytań, przeł. A. Wodnicki, Kraków 2004.

Janion M., Humanistyka. Poznanie i terapia, Warszawa 1982.

Lorenc I., Minima aesthetica. Szkice o estetyce późnej nowoczesności, Warszawa 2010. Markowski M.P., Zwrot etyczny w badaniach literackich, „Pamiętnik Literacki" 2000, z. 1 .

Nietzsche F., Poza dobrem i złem, przeł. P. Pieniążek, Kraków 2005.

Said E.W., Kultura i imperializm, przeł. M. Wyrwas-Wiśniewska, Kraków 2009. Savinio A., Nowa Encyklopedia, przeł. S. Kasprzysiak, Warszawa 2015.

„Teksty Drugie" 2002, nr 1-2.

„Teksty Drugie" 2005, nr 1-2.

Troczyński K., Od formizmu do moralizmu. Szkice literackie, [w:] K. Troczyński, Pisma wybrane, t. 1, Kraków 1997.

http:/ / malowane-wierszem.blogspot.com/2015/10/po-etyka-anna-piwkowska.html (dostęp: 23.07.2017).

http://wiadomosci.gazeta.pl/wiadomosci/1,114871,15684470,Kultowa_ margaryna_z_Murzynkiem_oburza_Afrykanczykow.html\#MT (dostęp: 23.07.2017).

\section{STRESZCZENIE}

Artykuł jest filipiką skierowaną przeciwko tak zwanej krytyce etycznej oraz etycznemu nastawieniu $w$ badaniach literaturoznawczych. Jednocześnie jego celem jest obrona autonomii i samoistnej wartości dzieł artystycznych, dewastowanych przez rozmaite etyzmy. Wpisuje się on w coraz wyraźniejszy we wspótczesnym literaturoznawstwie odwrót od badań etycznych i powrót do tekstu jako takiego. Jest to wynikiem rozpoznania, że etyki (w liczbie mnogiej, nie ma bowiem etyki uniwersalnej) to 
ostatecznie ideologie i swej logice są jedynie narzucaniem określonych idei innym. Jest to niesamowity paradoks - szlachetne założenia stają się niezgodne ze swymi realizacjami. Co zaskakujące, w takim, etycznym, odczytaniu każdorazowo tekst artystyczny staje się tym słabszym, mniej istotnym, wręcz - nieważnym. Oczywiście wybór estetyki zawsze jest narażony na zarzuty. Sam może być uznany za wybór etyczny, zatem ideologiczny. W końcu nawet biały kwadrat Malewicza został uznany za nieetyczny, ponieważ takie prace, jak dowodzono, poprzez odmowę uczestnictwa wspierają systemy władzy uznawane przez (nigdy wszystkich) za złe. Co na to można odpowiedzieć? Może to, że nie jest znany przypadek, by zwolennicy malarstwa abstrakcyjnego chcieli tym, którzy wolą malarstwo inne lub nie lubią obrazów w ogóle, coś nakazać, coś zakazać, do czegoś zmusić, coś odrzucić, coś przyjąć. Inaczej - obserwujemy to w codziennym doświadczeniu - z etykami. Ci najczęściej mają jedną rację - swoją. Dlatego ten tekst niczego nikomu narzucić nie pragnie.

\section{Słowa kluczowe}

krytyka etyczna, zwrot etyczny, estetyka, energia tekstu, energia sztuki

\section{SUMMARY}

\section{The Energy of Text. Against Ethical Criticism}

The article is a philippic aimed against so-called ethical criticism and the aesthetic attitude in literary studies. At the same time, however, its purpose is also to defend the autonomy and self-contained value of artistic works, which are devastated by miscellaneous "etisms". The article fits squarely into the more clearly visible, within literary studies, departure from ethical research and return to the text as such, which stems from the recognition that ethics (in plural, since there is no universal moral philosophy) are, after all, ideologies and, in their logic, only impose stipulated ideas upon others. And this is an extraordinary paradox, when noble assumptions turn out to be inconsistent with their implementations. Surprisingly, with each ethical reading, an artistic text becomes the weaker one, less significant and even unimportant. Naturally, the choice of aesthetics is always subject to accusations. And it may also be considered as an ethical choice, i.e. ideological in its nature. After all, even Malevich's white square was once regarded as unethical since it was argued that such works, through denial of participation, support power systems which are considered (not for all) to be evil. What can one say to that? Maybe that no case is known when aficionados of abstract painting wished to adapt, forbid, force or impose something upon those who prefer different types of

paintings or dislike any kinds of painting at all. The situation is different when it comes to ethicists, as we can see in everyday life. They usually have only one opinion - their own. And therefore, this article is not aimed at imposing anything upon anybody.

\section{Keywords}

ethical criticism, ethical turn, aesthetics, energy of text, energy of art 